\title{
TEMPO E ESPAÇO: INTERAÇÕES NA EDUCAÇÃO INFANTIL, DE Andréa Costa Garcia. SÃo Paulo: Senac, 2018, 138 P.
}

\author{
Adriana Siqueira Russo \\ Mestre em Educação pelo Programa de Gestão e Práticas \\ Educacionais da Universidade Nove de Julho - Uninove \\ São Paulo, SP - Brasil. \\ adrianasrusso@gmail.com
}

\begin{abstract}
Para citar - ABNT NBR 6023:2018
RUSSO, Adriana Siqueira. Resenha. Cadernos de Pós-graduação, São Paulo, v. 19, n. 2, p. 270-272, jul./dez. 2020. Resenha da obra de GARCIA, Andréa Costa. Tempo e espaço: interações na educação infantil. São Paulo: Senac, 2018, 138 p. Disponível em: https://doi.org/10.5585/cpg.v19n2.18096.
\end{abstract}

A Educação Infantil, de acordo com o artigo 29 da LDB, lei no 9394/96, compreende a primeira etapa da Educação Básica, que atende a bebês e crianças pequenas de 0 até 5 anos, e tem como objetivo principal promover o desenvolvimento integral dos pequenos, devendo proporcionar-lhes bem-estar físico, afetivo-social e intelectual, por meio de atividades lúdicas que criem oportunidades de desenvolvimento e que estimulem a curiosidade, a espontaneidade e as interações das crianças. Dessa forma, pesquisar sobre a organização do espaço e do tempo na escola infantil é de relevada importância para os educadores da infância, a fim de que possam conhecer e observar atentamente o grupo de crianças com que se relacionam e, então, a partir de suas necessidades, atribuir significado à estruturação espaço-temporal.

O livro Tempo e espaço: interações na Educação Infantil, de Andréa Costa Garcia, está divido em oito capítulos e aborda as interações na Educação Infantil, em especial, a organização dos tempos e espaços nas escolas da infância. No primeiro capítulo, a autora versa sobre a questão do planejamento na rotina da Educação Infantil, revelando sua importância. Aponta que ele não é neutro e não deve ser definido pelo professor de forma solitária, mas que deve ser um caminho coletivo e intencional. Explica o que é planejar e traz elementos essenciais ao planejamento, discorrendo sobre a importância de as crianças participarem ativamente desse processo, e aponta, por meio de exemplo, quanto o planejamento é necessário para que a diversidade e a inclusão sejam respeitadas.

No segundo capítulo, a autora discorre sobre a organização do espaço físico e sobre como esta influencia de forma significativa o percurso do ensino e da aprendizagem na Educação Infantil. Sob essa perspectiva, apresenta a organização do espaço de acordo com as teorias tradicional e 
interacionista, as concepções de criança incutidas nas instituições e nos educadores e os processos educativos próprios desse contexto. Dessa forma, nos revela que a perspectiva interacionista é um elemento essencial à constituição de um ambiente educativo, pois a maneira como os materiais e o mobiliário estão organizados nas instituições nos mostra a consideração concedida à criança como um sujeito autônomo, de direitos, criativo e capaz de se expressar.

A autora exemplifica possibilidades na adaptação dos espaços para a inclusão de crianças com deficiência e destaca que a constituição dos ambientes é de extrema importância, dado o número expressivo de crianças, desde a mais tenra idade, que passam a frequentar os espaços institucionais por cada vez mais tempo, permanecendo lá dez ou mais horas de seu dia.

O livro segue discorrendo sobre os processos de adaptação e de como eles assumem importância central na conquista da autonomia e na aquisição do sentimento de segurança básica dos bebês, das crianças pequenas e de suas famílias, envolvendo a instituição educacional como um todo. Aborda a teoria de Winnicott de que, em seus primeiros meses, um bebê sente que ele e a mãe se fundem e, por isso, no decorrer da adaptação, os objetos transicionais desempenham um papel essencial na garantia de uma separação mãe/bebê sem traumas. Segundo a autora, a forma de entender o transcurso da adaptação, assim como a organização dos espaços, também traz embutida uma concepção de criança a qual, se for respeitada, fará do pequeno um ser potente e com alta capacidade comunicativa desde os primeiros anos de vida. O que nos chamou a atenção é que, sob essa ótica, a autora determina que a criança assume um lugar ativo nos contextos dos quais participa, porém nos questionamos se a postura autocêntrica adotada por algumas instituições não é de mera reprodução das ações sem intencionalidade e significações no fazer docente, pensada a priori para atender aos regimentos. Envolver todos os atores nesse processo é fundamental à instauração de uma ponte segura a partir de um planejamento sensível e cuidadoso.

A intencionalidade e a significação da prática docente são reafirmadas ao longo de todo o livro, especialmente no capítulo que trata das relações entre as famílias e as escolas da infância, no qual a autora exemplifica, de maneira didática, as possibilidades de assegurarem-se condições favoráveis ao assentamento de alianças entre educadores e pais e evidencia as benesses oriundas do trabalho docente pautado na teoria interacionista. Porém, apesar de a autora destacar por diversas vezes a relevância dessa teoria, ela não é contextualizada, nem em seu processo histórico nem em sua escolha pessoal em abordá-la.

Os capítulos finais tratam de maneira sensível, muito didática e sem prescrição, da importância das interações e como promovê-las nas instituições; discute questões sobre tempo e espaço, avaliação e projetos. O livro nos remete a uma narrativa voltada à sensibilização dos temas apresentados, visando a que os projetos tragam consigo intencionalidade e significado, 
possibilitando que a avaliação respeite as especificidades de cada faixa etária envolvida no processo.

Nesta avaliação devem destacar-se os múltiplos registros, asseverando a observação crítica e criativa das atividades, brincadeiras e interações estabelecidas no cotidiano escolar, bem como a viabilização de seus fazeres e saberes, tendo a criança como sujeito que apresenta inúmeras potencialidades.

Todos os capítulos norteiam-se pela intencionalidade e ressignificação da prática docente, sinalizando que em todas as situações devem estar presentes a empatia e a sensibilização. O livro nos revela um grande conhecimento da autora acerca das especificidades dos bebês e crianças pequenas e de suas rotinas nas instituições.

Ademais, a forma com que todo o livro foi pensado e escrito mostra a coerência da autora em dar continuidade aos temas considerados por ela imprescindíveis à realização de um fazer pedagógico que respeite os bebês e as crianças pequenas. 